\title{
Comparison of fouling of raw milk and whey protein solution on stainless steel and fluorocarbon coated surfaces: Effects on fouling performance, deposit structure and composition
}

\author{
Ole M. Magens ${ }^{\mathrm{a}}$, Jurgen F. A. Hofmans ${ }^{\mathrm{b}}$, Yves Adriaenssens ${ }^{\mathrm{b}}$, D. Ian Wilson ${ }^{\mathrm{a}, *}$ \\ ${ }^{a}$ Department of Chemical Engineering and Biotechnology, Philippa Fawcett Drive, Cambridge, CB3 OAS, UK \\ ${ }^{b}$ Chemours Belgium BVBA, A. Spinoystraat 6A, B-2800 Mechelen, Belgium
}

\begin{abstract}
Fouling from raw milk and from whey protein solutions mimicking the protein content of milk have been performed at two length scales, using a microfluidic heat transfer cell and a bench-scale device with hydraulic diameters $1.0 \mathrm{~mm}$ and $16.1 \mathrm{~mm}$, respectively. The microfluidic cell allows raw milk to be studied in once-through mode and was used to identify polymer coated surfaces to test against stainless steel. Several of the fluorocarbon coated surfaces reduced the mass deposition but the pressure drop and thermal resistance did not match these directly, indicating that the nature and structure of the deposit is affected by the surface. A fluorinated ethylene propylene coating was identified as a promising candidate for large scale tests. At the interface with apolar surfaces, raw milk fouling layers were high in protein whereas a strongly attached mineral-rich layer was present at the interface with steel. The attraction of denatured protein towards apolar surfaces and the formation of a calcium phosphate layer on steel at later stages of fouling are explained with arguments based on the interfacial free energy of these materials in water.
\end{abstract}

Keywords: Milk fouling, Coating, Fluoropolymer, Pasteurisation, Beta-lactoglobulin, Calcium phosphate

\section{Introduction}

Milk fouling and surfaces. Surface coatings and surface modifications have been advocated for mitigating fouling in the food industry for some time (e.g. Rosmaninho and

5 Melo, 2007; Mérian and Goddard, 2012; Boxler et al., 2013). Several fluoropolymer (FP) and FP derivative/composite surfaces have been tested for dairy applications as their low surface energies make the attachment of deposits less favourable (Barish and Goddard, 2013, 2014). FP coatings, however, introduce additional thermal resistance as the layer must be several microns thick in order to resist abrasion and allow good adhesion to the substrate. There is thus a trade-off between coating thickness, antifouling performance and cost (Gomes da Cruz et al., 2015).

Milk contains several species which potentially contribute to fouling, particularly whey proteins (WPs), calcium phosphate and lipids. These interact differently with the stainless steel (SS) used as standard in dairy processing equipment and those interactions dictate which species are deposited initially (Piepiórka-Stepuk et al., 2016) and thereafter. Since the purpose of a modified or coated surface is to deter the initiation of fouling and to reduce the rate of any subsequent deposition, the interaction of such species with the coating needs to be considered rather

\footnotetext{
* Corresponding author

Email address: diw11@cam.ac.uk (D. Ian Wilson)
}

assuming that these will be similar to those on steels. Many studies of dairy fouling and cleaning have employed WP solutions rather than raw milk to identify and quantify the dominant mechanisms involved in dairy fouling, with some success (e.g. Blanpain-Avet et al., 2016). Translating results from model solutions to practice is subject to variations induced by the minor fouling components (Huang and Goddard, 2015). Furthermore, any coating must endure the changes in chemical environments associated with repeated fouling and cleaning cycles. There is therefore a need to test using raw milk.

In this work, fouling experiments were performed using raw milk and $1.82 \% \mathrm{~g} \mathrm{~g}^{-1} \mathrm{WP}$ concentrate solutions which reflect the WP concentration of bovine milk. Since raw milk is microbacterially active, a microfluidic heat exchanger (HEX) was used to assess the fouling propensity of different coatings compared to 304 SS. This required a small (2 litre) liquid inventory and operated in oncethrough mode. Selected coatings were subsequently tested in a bench-scale flow cell using raw milk and WP solution in which the liquid was recirculated. The bulk liquid was maintained at $61^{\circ} \mathrm{C}$, at which temperature insignificant denaturation of protein was expected to occur (Walstra et al., 2005). The test section of this cell employed turbulent flow conditions and the initial surface temperatures so were similar to those in the microfluidic HEX. Both devices employed flat, heated plates so the deposits could be readily inspected in situ after testing. 


\begin{tabular}{|c|c|c|}
\hline \multicolumn{3}{|c|}{ Nomenclature } \\
\hline \multicolumn{3}{|c|}{ Greek Symbols } \\
\hline$\gamma$ & Surface free energy & $\mathrm{mJ} \mathrm{m}^{-2}$ \\
\hline$\Delta$ & Difference operator & \\
\hline$\delta$ & Thickness & $\mu \mathrm{m}$ \\
\hline \multicolumn{3}{|c|}{ Roman Symbols } \\
\hline$G$ & Free energy per area & $\mathrm{mJ} \mathrm{m}^{-2}$ \\
\hline$k$ & Thermal conductivity & $\mathrm{W} \mathrm{m}^{-1} \mathrm{~K}^{-1}$ \\
\hline$m$ & Mass & $\mathrm{kg}$ \\
\hline$\dot{m}$ & Mass flow rate & $\mathrm{kg} \mathrm{s}^{-1}$ \\
\hline$P$ & Pressure & $\mathrm{Pa}$ \\
\hline$q$ & Heat duty & $\mathrm{W}$ \\
\hline$S_{\mathrm{a}}$ & Arithmetic mean roughness & $\mathrm{nm}$ \\
\hline$T$ & Temperature & $\mathrm{K}$ \\
\hline$\dot{V}$ & Volumetric flow rate & $\operatorname{lmin}^{-1}$ \\
\hline \multicolumn{3}{|c|}{ Superscripts } \\
\hline+ & Electron acceptor & \\
\hline- & Electron donor & \\
\hline IF & Interfacial & \\
\hline LW & Lifshitz-van der Waals interactions & \\
\hline \multicolumn{3}{|c|}{ Subscripts } \\
\hline $1,2,3$ & Medium 1,2,3 & \\
\hline $\mathrm{b}$ & Bulk & \\
\hline coat & Coating & \\
\hline e & Electrical & \\
\hline $\mathrm{f}$ & Fouling & \\
\hline h & Heater, Hot side & \\
\hline in & Inlet & \\
\hline out & Outlet & \\
\hline \multicolumn{3}{|c|}{ t1,t2,t3 Tank 1, 2, 3} \\
\hline $\mathrm{w}$ & Wall & \\
\hline
\end{tabular}

Particle-surface forces. In an aqueous environment the 85 forces between an (inert) substrate and an adhering species are determined by contributions from electrostatic, Van der Waals, and solvation forces (Israelachvili, 2011). One approach which has been applied successfully in many situations is the extended Derjaguin, Landau, Verwey and 90 Overbeek (XDLVO) theory (van Oss, 2003). This theory superimposes energies of interaction from Van der Waals, Lewis acid-base, and electric double layer forces.

The electric double layer repulsion of particles arises from the osmotic pressure of counterions attracted by sur- 95 face charges (Israelachvili, 2011). It decays spatially with 5 the characteristic Debye length, which is solely a property of the solution and decreases with increasing ionic strength. The ionic strength of milk is $80 \mathrm{mM}$ (Walstra et al., 2005), which gives a Debye length of $1 \mathrm{~nm}$, i.e. the electric potential reduces to $1 / e \approx 37 \%$ within the first nanometre (van Oss, 2003). This renders effects from osmotic pressure negligible compared to the other two forces within the XDLVO framework. Auspiciously, Van der Waals and Lewis acid-base interactions can be considered collectively in some theories describing surface energy. Van Oss et al. (1987) split surface energy, $\gamma$, into LifshitzVan der Waals, $\gamma^{\mathrm{LW}}$, acidic, $\gamma^{+}$(electron acceptor), and basic, $\gamma^{-}$(electron donor), contributions to yield $\gamma=$ $\gamma^{\mathrm{LW}}+2 \sqrt{\gamma^{+} \gamma^{-}}$.

Interfacial energies obey the geometric mean 'combination rules' described by Fowkes (1963). For cases where both apolar and polar interactions operate across an interface between material 1 and 2, van Oss et al. (1987) showed that the interfacial energy at molecular contact is given by

$$
\begin{aligned}
\gamma_{12}= & \left(\sqrt{\gamma_{1}^{\mathrm{LW}}}-\sqrt{\gamma_{2}^{\mathrm{LW}}}\right)^{2} \\
& +2\left(\sqrt{\gamma_{1}^{+} \gamma_{1}^{-}}+\sqrt{\gamma_{2}^{+} \gamma_{2}^{-}}-\sqrt{\gamma_{1}^{+} \gamma_{2}^{-}}-\sqrt{\gamma_{2}^{+} \gamma_{1}^{-}}\right)
\end{aligned}
$$

Here, $\gamma_{\mathrm{i}}$ is the surface energy between substance $\mathrm{i}$ and vacuum: the subscript for vacuum is omitted here for convenience, as in many texts. Moreover, $\gamma_{\mathrm{i} \text {,air }} \approx \gamma_{\mathrm{i}}$. The interfacial free energy of interaction in an immersed system is estimated from the difference in total interfacial energy when adsorbing species 1 contacts a substrate 2 in medium 3. Note that in the literature, subscript 2 sometimes refers to the surrounding medium. As outlined by van Oss et al. (1987), following arguments of Dupré (1869), the interfacial free energy of interaction is given by

$$
\Delta G_{123}^{\mathrm{IF}}=\gamma_{12}-\gamma_{13}-\gamma_{23},
$$

where $\gamma_{12}, \gamma_{13}$ and $\gamma_{23}$ are the interfacial energies between respective materials at contact, i.e. minimum equilibrium distance. Figure 1(a) illustrates the process for a polymer strand adsorbing to a surface in water. The adsorbing strand displaces the interstice medium, i.e. it replaces the particle-water and surface-water interfaces with a particlesurface interface. Aggregation and dissolution of like particles, as shown in Figure 1(b), can be understood as a similar process (van Oss and Good, 1992). Type A milk fouling deposit generated below $100{ }^{\circ} \mathrm{C}$ is mainly a product of aggregated protein which forms a porous matrix with a large water content (Bansal and Chen, 2006; Hagsten et al., 2016). Besides chemical bonds, the physical interactions within the wet protein matrix contribute to the cohesion of the material. Therefore, the interfacial free energy of interaction of protein chains within this matrix provides an important contribution to cohesion. 
(a)

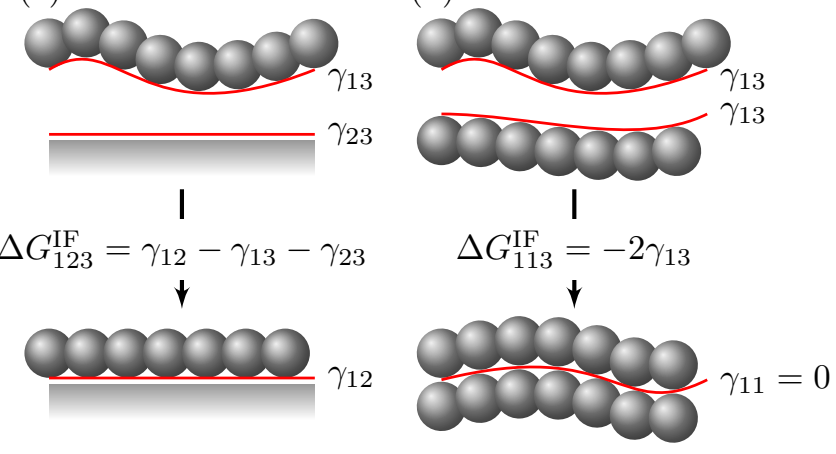

Figure 1: Schematic of a particle (here, a polymer strand) (a) adsorbing to a surface and (b) aggregating with a second particle of identical nature. The interfacial free energies of interaction associated with these processes are presented in the centres of the schematics. The relevant interfaces are highlighted with red lines. The subscripts denote: 1 - particle; 2 - surface; 3 - water.

$\Delta G_{123}^{\mathrm{IF}}$ can be positive or negative depending on the materials involved. If medium 3 is aqueous and $\Delta G_{123}^{\mathrm{IF}}<$ 0 , species 1 and substrate 2 exhibit a hydrophobic attraction and, conversely, hydrophilic repulsion if $\Delta G_{123}^{\mathrm{IF}}>0$. $\Delta G_{123}^{\mathrm{IF}}=0$ represents the special case of no net interaction.

\section{Materials and Methods}

Microscale test cell. A detailed description of the microfluidic fouling cell (Figure 2 and 3) has been reported by Magens et al. (2017). Liquid is pumped from one of three reservoirs maintained at $56{ }^{\circ} \mathrm{C}$ through a copper preheater coil immersed in a hot water bath which raises the liq- ${ }^{13}$ uid temperature before it enters the test section. The test section is a $2 \mathrm{~mm}$ wide by $0.65 \mathrm{~mm}$ high rectangular chanwhose top wall is provided by part of a $50 \times 50 \mathrm{~mm}$ square test plate. Heating is provided over the central $40 \mathrm{~mm}$ length of the channel by an electrical heating ele- ${ }^{140}$ ment. The electrical heating power, inlet and outlet temperatures, and pressure drop across the channel were monitored during an experiment. The bottom wall of the test cell was made from glass so that deposition could be inspected in situ using optical or confocal laser scanning ${ }^{145}$ microscopy (CLSM).

Fouling experiments were performed under constant milk flow rate $\left(12 \mathrm{~g} \mathrm{~min}^{-1}\right)$ and constant heat flux conditions. The bulk liquid temperature increased from $62{ }^{\circ} \mathrm{C}$ (Reynolds number $=213 \pm 12$ ) to $68^{\circ} \mathrm{C}$ and the surface ${ }^{150}$ temperature ranged from approximately 75 to $91^{\circ} \mathrm{C}$, so that $\beta$-lactoglobulin was expected to be in the molten globthe bulk. Deionised water was passed through the system until it reached thermal steady state, at which point the feed was ${ }^{155}$ switched to deaerated raw milk for two hours. The test cell was disassembled to recover the plate and the sys- (a)

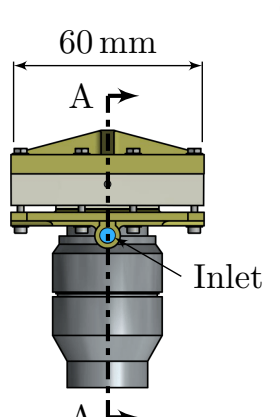

(b)

Section A-A

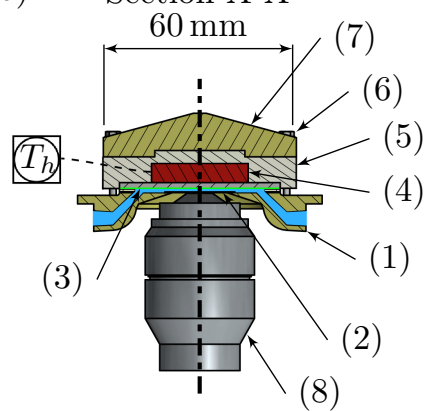

(c) 2.5

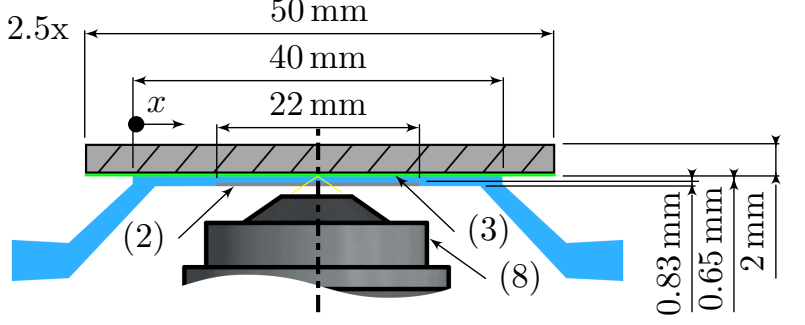

Figure 2: Microfluidic HEX assembly. (a) Side view, inlet facing front. (b) Cross section through plane AA showing channel, sample and heater. (c) Magnification of (b) showing sample and channel geometry. Labels -1 , channel body (nylon); 2, window; 3, flow channel; 4, heater; 5 , copper block; 6 , securing bolts; 7 , top section; 8 , microscope. The width of the channel is $2 \mathrm{~mm}$. Dash-dot lines indicate planes of symmetry.

lowed by deionised water. The test plates were reused: the clean performance was recorded to determine any changes in thermal performance.

Visualising protein and calcium phosphate. Confocal microscopy was used to study the distribution of calcium phosphate and protein within the fouling layers. Calcium green A1 (CG) and texas red sulfonyl chloride (TR-SC) (both Molecular Probes Inc.) show an increase in fluorescence on binding to calcium ions and amine groups, respectively. $50 \mu \mathrm{g}$ of CG was dissolved in $50 \mu \mathrm{L}$ dimethyl sulfoxide (purity $0.99 \mathrm{~g} \mathrm{~g}^{-1}$, Alfa Aesar) under ultra-sonication and added to $10 \mathrm{ml}$ deionised water. The final concentration of $4 \mu \mathrm{M}$ is in the order of magnitude used by Thomas et al. (2000) to study calcium cell signalling. The solution was injected into the microfluidic HEX cell holding the fouling deposit and kept there for $25 \mathrm{~min}$. Afterwards, $1 \mathrm{mg}$ of TR-SC was dissolved in $10 \mathrm{ml}$ deionised water just above the water freezing point to reduce the rate of dye hydrolysis (Lefevre et al., 1996). The $160 \mu \mathrm{M}$ TR-SC solution was injected into the cell shortly after mixing and again held therein for $25 \mathrm{~min}$. The cell was then rinsed with deionised water and placed on a Leica TCS SP5 CLSM. The CG and TR-SC fluorophores were excited by an argon laser at $514 \mathrm{~nm}$ and a helium-neon laser at $633 \mathrm{~nm}$, respectively. In situ images of deposits on FPs were taken with a $10 \times$ lens and the pinhole set to $53 \mu \mathrm{m}$. In some cases, deposits adhered strongly enough to be imaged ex-situ using a $40 \times$ oil immersion lens. 


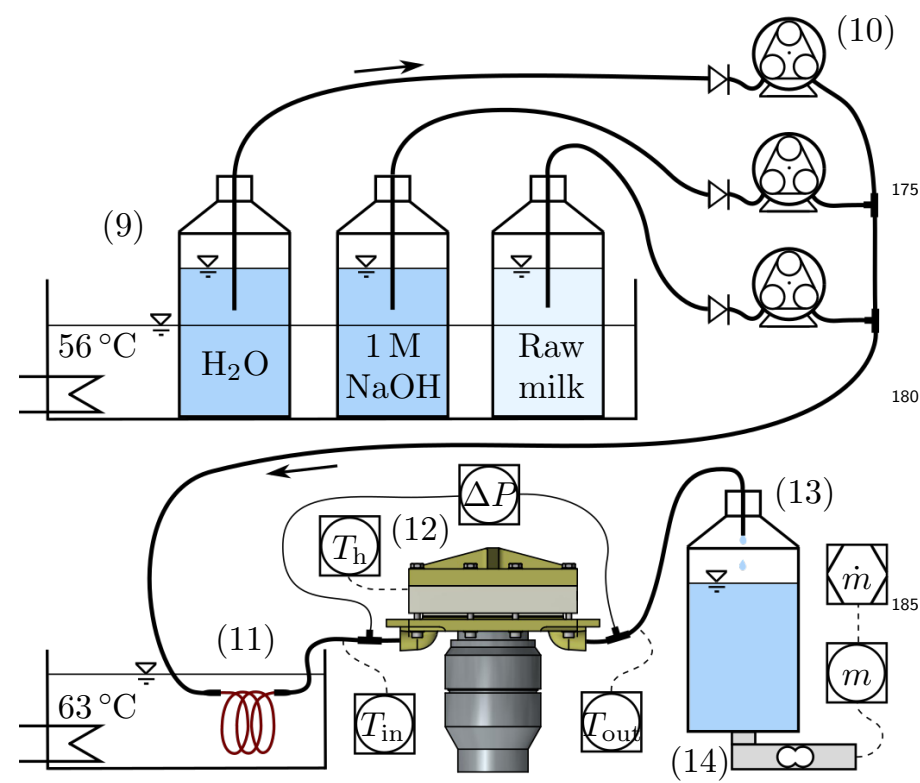

Figure 3: Microfluidic HEX process schematic. Labels - 9, thermostat; 10, pumps; 11, preheater; 12, fouling cell; 13 , waste receiver; 14 , balance

Bench-scale test cell. The test section in this unit featured a long rectangular flow channel, $42 \mathrm{~mm}$ wide and $10 \mathrm{~mm}$ high, mounted vertically to inhibit bubble attachment. Bubble formation was further inhibited by operating at an overpressure of 0.8 bar. Liquid was pumped ${ }^{200}$ from one of three 171 reservoirs, illustrated in Figure 4, through the test section at $8.00 \pm 0.181 \mathrm{~min}^{-1}$ (mean velocity $0.32 \pm 0.07 \mathrm{~m} \mathrm{~s}^{-1}$ ) and an inlet temperature of $61^{\circ} \mathrm{C}$, giving an inlet Reynolds number of 6900 for milk and 11100 for whey protein solution. The high flow rate meant ${ }^{205}$ that the feed had to be recirculated. The tank holding the stricted to $63^{\circ} \mathrm{C}$ in order to inhibit fouling on the wall and denaturation of protein in the bulk. The test plate was heated by electric heaters operating at constant heat flux. Deposition had relatively little effect on pressure drop so deposition was monitored by changes in overall heat transfer coefficient, expressed as fouling resistance, $R_{\mathrm{f}}$. Separate heat transfer tests using thermochromic liquid crystals allowed the film heat transfer coefficient, and thus the initial surface temperature, to be determined directly. The Gnielinski correlation (Bergman and Incropera, 2011) for hydrodynamically and thermally developed flow described the mean film heat transfer coefficient reasonably well. The mean surface temperature was set at $89^{\circ} \mathrm{C}$ in tests with whey protein solution and at $92.5^{\circ} \mathrm{C}$ in tests with raw milk to generate sufficient deposition. The system was initially brought to operating temperatures by recirculating and heating deionised water before switching over to the fouling solution. At the completion of a test heating was discontinued and the recirculating liquid switched over to water until the plate temperature fell to $70^{\circ} \mathrm{C}$, at which point the flow was stopped, the test section removed, and cleaning in place started with circulation of $0.2 \mathrm{M} \mathrm{NaOH}$ solution and deionised water at $60^{\circ} \mathrm{C}$.

The configuration of the test section ( $42 \mathrm{~mm}$ wide channel, $50 \mathrm{~mm}$ long test plate, fully developed velocity profile) meant that the thermal boundary layer thickness and surface temperature varied over the plate. Deposition was therefore not uniform, being greater near the edges and downstream. Surface temperature isotherms were expected to be quasi-parabolic near the start of the heated section and this was conformed with tests using a temperature sensitive thermochromic liquid crystal coating shown in Figure 5(a). Heat transfer experiments with the liquid crystal coated sample were conducted at lower operating temperatures than during the fouling tests. Starting at $39.9^{\circ} \mathrm{C}$, the black coating changed colour to red, green, blue, and back to black again. The temperature distribu-

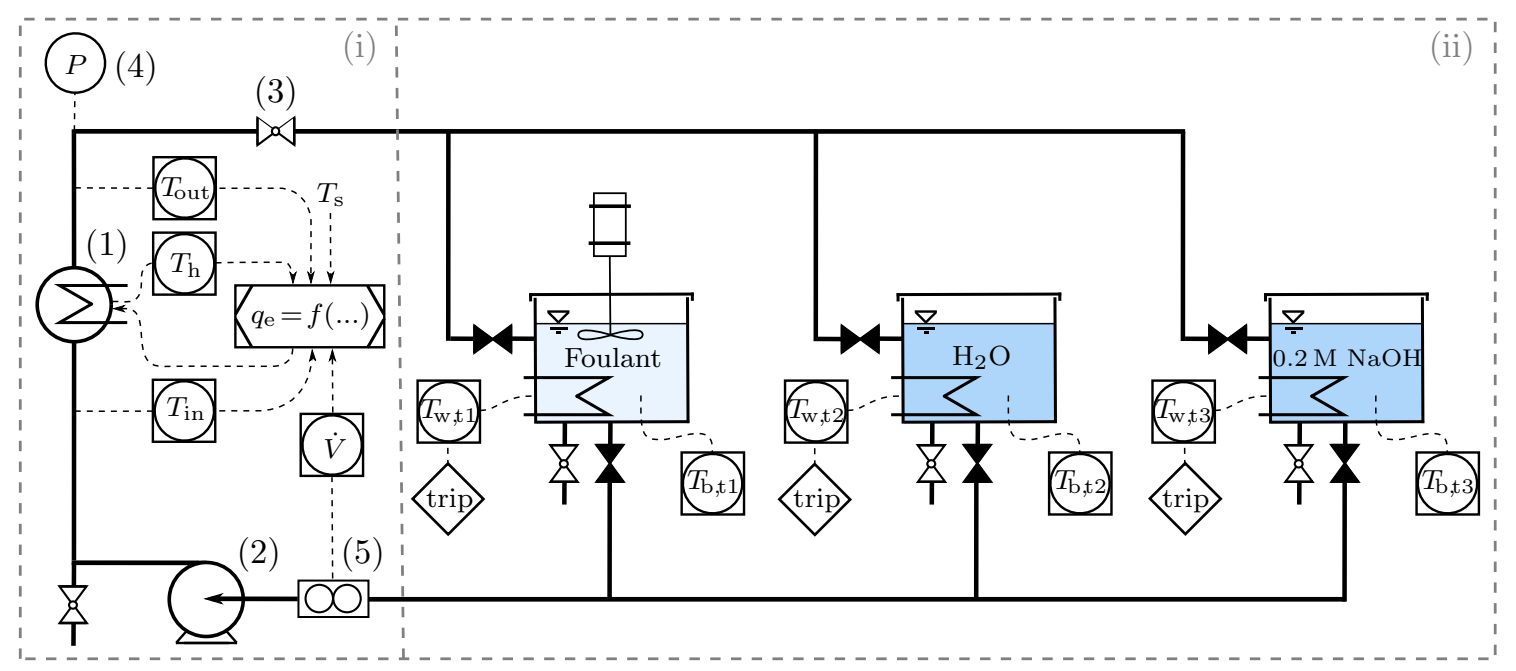

Figure 4: Bench-scale HEX process schematic with labelled sub-systems: (i) flow channel with HEX and (ii) heated tanks and pump. T temperature, $\dot{V}$ - flow rate. Numerical labels discussed in the text. 
tion was also evident in the wet deposit distribution (Figure 5b) and in measurements of dry deposit layer thickness obtained using a confocal thickness sensor (Figure 5c).

(a)

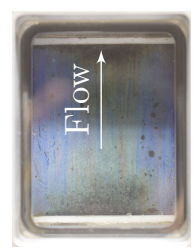

(b)

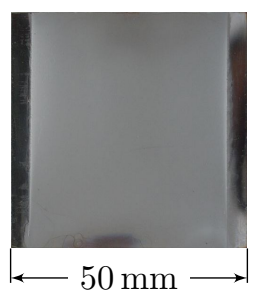

(c)

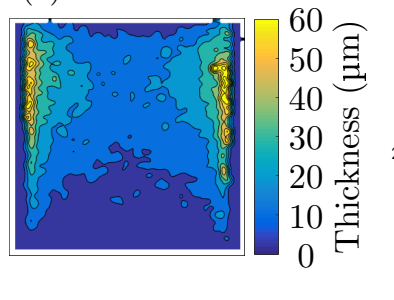

Figure 5: Effect of thermal boundary layer development on (a) heat transfer: blue colour change of thermochromic liquid crystal coating ${ }^{240}$ indicates that the surface temperature is greater than $40^{\circ} \mathrm{C}$; (b) wet deposit from whey protein solution on uncoated SS; (c) thickness of dry deposit. Scale: $50 \times 50 \mathrm{~mm}$.

Surface samples. All test surfaces were based on $2 \mathrm{~mm}^{245}$ thick, $50 \mathrm{~mm}$ square $304 \mathrm{SS}$ plates with surface finish EN 10088-2 2R. A range of coatings were applied by Chemours Belgium and the properties of the uncoated and coated pates are summarised in Table 1. The thermal conductivity of the coatings were obtained from heat transfer ${ }^{250}$ measurements in the test cells. The coated surfaces were more hydrophobic and less smooth than the SS reference. Surface energy components were determined by contact (CA) measurements of water, formamide, ethylene glycol, dodecane and diiodomethane. The CA measured ${ }^{255}$ on water is reported in Table 1: the values obtained with other probe liquids, used to determine surface energy components using Equation 1 and the Young-Laplace equation (e.g. van Oss, 2003), are reported in Supplementary Table 1.
The surface energies of some important species involved in milk fouling were also characterised or reproduced from the literature: $\beta$-lactoglobulin $(\beta$-LG), milk fat globule (MFG), dicalcium phosphate dihydrate (DCPD), octacalcium phosphate (OCP) and hydroxyapatite (HAP). A thin film of denatured and polymerised $\beta$-LG (Sigma Aldrich, purity $\geq 90 \%$, variant $A$ and B) was generated by wetting a SS sample with a $1 \mathrm{gl}^{-1}$ solution in reverse osmosis 5 water and subsequent air drying for $20 \mathrm{~min}$ in an oven at $90{ }^{\circ} \mathrm{C}$. Contact angles of test liquids with the $\beta$-LG layer were determined by taking videos with a camera attached to the goniometer to capture the instant before the layer started to wick the sessile drops noticeably.

Test solutions. Raw milk was obtained from Holstein-Friesian cattle at the University of Cambridge's Park Farm and used immediately. Analysis of the milk gave calcium content of $0.10 \% \mathrm{~g} \mathrm{~g}^{-1}$, fat $3.8 \% \mathrm{~g} \mathrm{~g}^{-1}$, protein $3.1 \% \mathrm{~g} \mathrm{~g}^{-1}$ and $0.8 \% \mathrm{gg}^{-1}$ ash. For tests with the microfluidic cell the milk was deaerated for $45 \mathrm{~min}$ in an ultrasonic bath at $20 \mathrm{kPa}$ (absolute) and $56{ }^{\circ} \mathrm{C}$. Its $\mathrm{pH}$ decreased from $6.70 \pm 0.24$, as received, to $6.30 \pm 0.06$ during heating and increased slightly during subsequent degassing. CLSM images of the milk indicated no visible effect of the procedure on the milk fat globules. For tests with the bench-scale test cell, $17 \mathrm{l}$ of unmodified milk were heated to $61^{\circ} \mathrm{C}$ under gentle stirring in the experimental rig over $90 \mathrm{~min}$. The $\mathrm{pH}$ of the milk was monitored and reduced slightly from 66 to 6.5 over the duration of the $2.5 \mathrm{~h}$ test.

WP solutions were prepared by dissolving WP concentrate (WPC35) provided by Friesland Campina (Waageningen, NL) in reverse osmosis water to give a 1.94 $\% \mathrm{gg}^{-1}$ solution. The final solution had a calcium content of $0.01 \% \mathrm{~g} \mathrm{~g}^{-1}$, fat $0.04 \% \mathrm{gg}^{-1}$, whey protein 0.62 $\% \mathrm{~g} \mathrm{~g}^{-1}$, lactose $0.93 \% \mathrm{~g} \mathrm{~g}^{-1}$ and $0.12 \% \mathrm{~g} \mathrm{~g}^{-1}$ ash. The $\mathrm{pH}$ of WP solution remained stable at 6.7 during tests with

Table 1: Surface energies and coating characteristics. CA is the contact angle on water; $\gamma$ the surface energy components (LW apolar component;,+- van Oss acid-base); $\delta_{\text {coat }}$ and $k_{\text {coat }}$ the coating thickness and thermal conductivity, respectively; $S_{\text {a }}$ the arithmetic mean roughness. \pm indicates standard deviation. Colours in the first column are labels to identify surfaces in other figures throughout this article.

\begin{tabular}{|c|c|c|c|c|c|c|c|}
\hline Surface & $\begin{array}{l}\mathrm{CA} \\
\left({ }^{\circ}\right)\end{array}$ & $\begin{array}{l}\gamma^{\mathrm{LW}} \\
\left(\mathrm{mJ} \mathrm{m}^{-2}\right)\end{array}$ & $\begin{array}{l}\gamma^{+} \\
\left(\mathrm{mJ} \mathrm{m}^{-2}\right)\end{array}$ & $\begin{array}{l}\gamma^{-} \\
\left(\mathrm{mJ} \mathrm{m}^{-2}\right)\end{array}$ & $\begin{array}{l}\delta_{\text {coat }} \\
(\mu \mathrm{m})\end{array}$ & $\begin{array}{l}k_{\text {coat }} \\
\left(\mathrm{W} \mathrm{m}^{-1} \mathrm{~K}^{-1}\right)\end{array}$ & $\begin{array}{l}S_{\mathrm{a}} \\
(\mathrm{nm})\end{array}$ \\
\hline SS & $57.1 \pm 2.6$ & $32.3 \pm 0.7$ & $8.7 \pm 6.0 \times 10^{-4}$ & $32.6 \pm 1.7$ & - & - & $40 \pm 3$ \\
\hline PP & $103.5 \pm 1.1$ & $28.5 \pm 0.5$ & $49 \pm 10 \times 10^{-4}$ & $0.26 \pm 0.11$ & $31.8 \pm 7.3$ & $0.106 \pm 0.027$ & $154 \pm 33$ \\
\hline PFA-2 & $110.3 \pm 2.3$ & $16.1 \pm 1.2$ & $2.3 \pm 5.4 \times 10^{-4}$ & $0.53 \pm 0.33$ & $102.0 \pm 8.2$ & $0.273 \pm 0.039$ & $494 \pm 47$ \\
\hline PFA-3 & $108.2 \pm 2.5$ & $16.9 \pm 1.0$ & $8.2 \pm 8.1 \times 10^{-4}$ & $0.93 \pm 0.35$ & $71.2 \pm 3.5$ & $0.266 \pm 0.039$ & $556 \pm 67$ \\
\hline PFA-4 & $108.0 \pm 1.2$ & $18.0 \pm 0.9$ & $4.6 \pm 5.6 \times 10^{-4}$ & $1.0 \pm 0.3$ & $44.6 \pm 6.7$ & $0.123 \pm 0.021$ & $459 \pm 79$ \\
\hline FEP-2 & $108.4 \pm 1.4$ & $16.9 \pm 1.0$ & $8.6 \pm 9.1 \times 10^{-4}$ & $0.76 \pm 0.35$ & $57.8 \pm 3.3$ & $0.146 \pm 0.021$ & $381 \pm 78$ \\
\hline FEP-3 & $108.1 \pm 0.6$ & $16.3 \pm 0.8$ & $8.5 \pm 7.2 \times 10^{-4}$ & $1.1 \pm 0.3$ & $54.4 \pm 4.8$ & $0.155 \pm 0.017$ & $216 \pm 35$ \\
\hline PTFE-1 & $81.1 \pm 4.4$ & $23.8 \pm 1.5$ & $0.18 \pm 0.16$ & $11.5 \pm 1.7$ & $41.8 \pm 3.4$ & $0.124 \pm 0.021$ & $741 \pm 73$ \\
\hline$\beta-\mathrm{LG}$ & $82.1 \pm 2.2$ & $36.1 \pm 0.9$ & $6 \pm 50 \times 10^{-4}$ & $6.1 \pm 0.8$ & & & \\
\hline $\mathrm{DCPD}^{1}$ & not reported & 26.4 & 1.6 & 31.7 & & & \\
\hline $\mathrm{OCP}^{1}$ & not reported & 21.6 & 2.2 & 19.7 & & & \\
\hline $\mathrm{HAP}^{1}$ & not reported & 36.2 & 0.9 & 16.0 & & & \\
\hline
\end{tabular}

1 data from $\mathrm{Wu}$ and Nancollas $(1998)$ 
the bench-scale cell. The thermophysical properties of WP solution and milk were approximated to be those of water apart from the viscosity of raw milk, which was taken from Fernández-Martín (1972) for milk with $10 \% \mathrm{~g} \mathrm{~g}^{-1}$ total solids content.

\section{Results}

Microscale testing: screening candidate surfaces. Figure 6 shows that the change in pressure drop was more marked on the perfluoroalkoxy (PFA) coatings than on the SS, despite the latter being more hydrophilic and having a higher surface energy. The induction time before significant deposition started for PFA-3 was similar to that on the steel, whereas it was effectively zero for PFA-2. The trends were reproducible. The polytetrafluoroethylene (PTFE) epoxy composite coating performed similarly to the steel, and the fluorinated ethylene propylene (FEP) coating fouled less, with an induction time of approximately one hour.

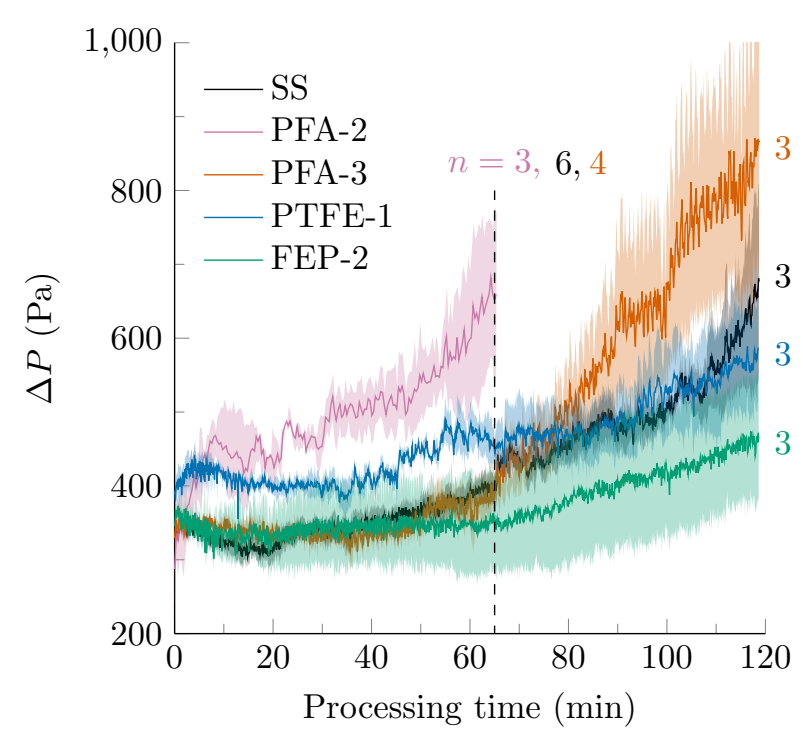

Figure 6: Pressure drop profiles for fouling tests with raw milk using the microfluidic test cell. $n$ indicates the number of experiments performed. Shaded bands indicate \pm standard error.

The mass of deposit, expressed as the coverage per unit area, $m_{\mathrm{f}}$, in Figure 7 shows some differences. The $m_{\mathrm{f}}$ values for PFA-2 and PTFE-1 are similar to the steel, as are the $\Delta P$ values at the end of the tests. That for PFA-3 is noticeably smaller, even though $\Delta P$ was larger, while that for FEP-2 was lower, but not statistically different from PFA-3. These results indicate that the nature of the deposit differed between the surfaces, which is evident in the photographs of dry deposits in Figure 8 . The deposit on many of the fluoropolymer surfaces cracked and peeled, indicating that the deposit was more cohesive and 290 had weak adhesive interactions upon drying. In the liquid phase (immersed in water or milk) the deposits were uniform and did not spontaneously detach, highlighting the

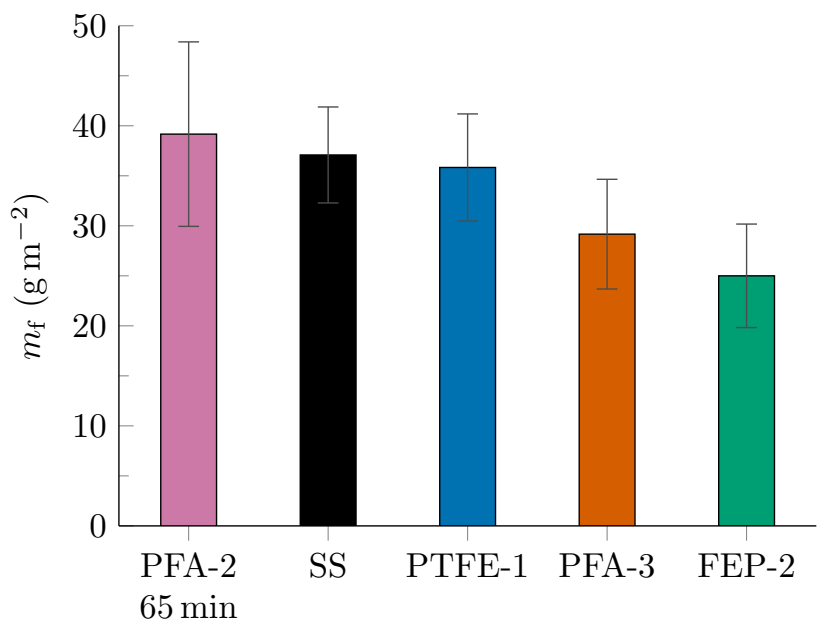

Figure 7: Dry deposit mass per unit area from raw milk after a test duration of $120 \mathrm{~min}$ (except for PFA-2: $65 \mathrm{~min}$, see Figure 6). Error bars show $90 \%$ confidence intervals based on three repeats.

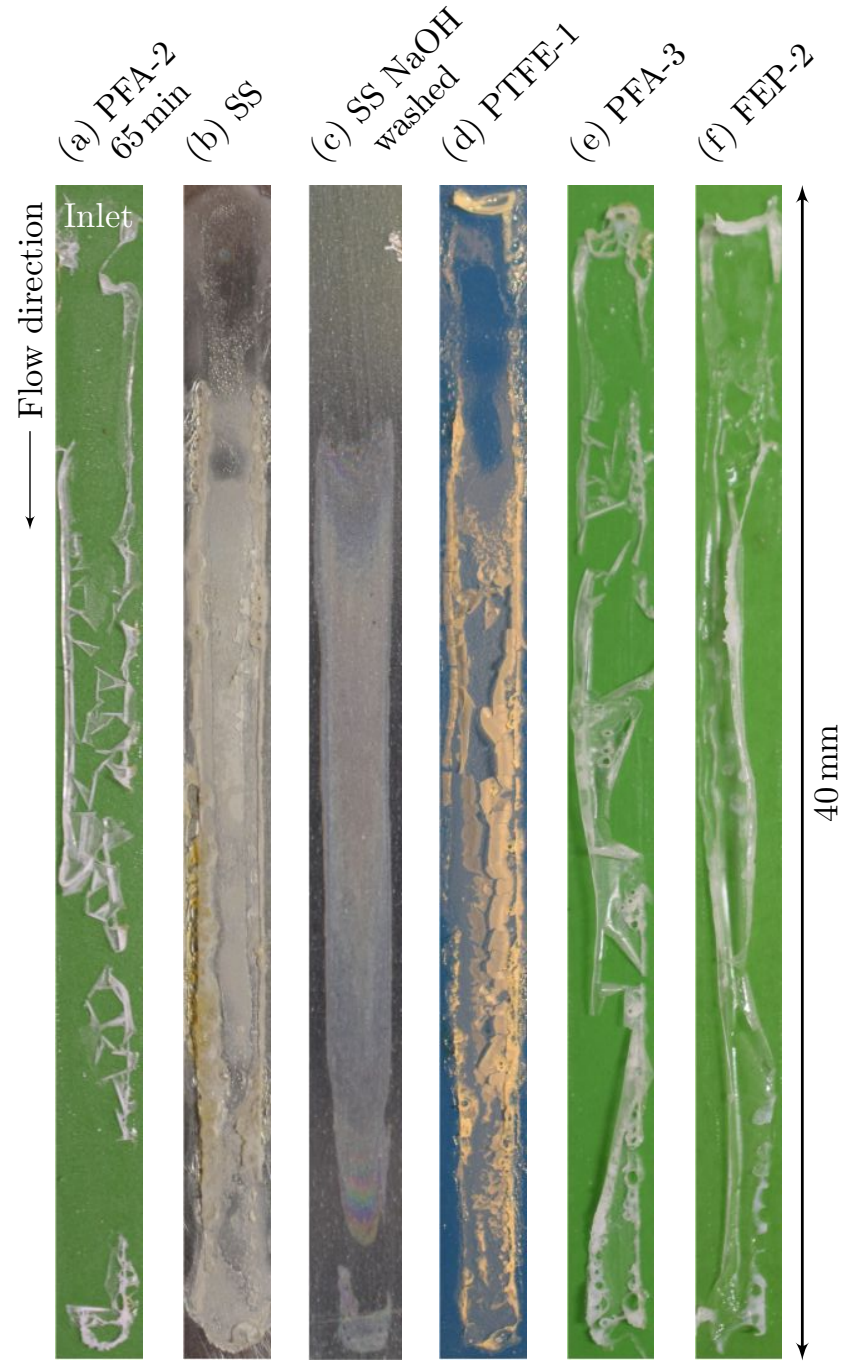

Figure 8: Photographs of raw milk deposits on microfluidic test sections after drying. 
need to consider water-foulant-substrate surface interactions.

The deposits formed on FEP and PFA could be removed completely with $\mathrm{NaOH}$, whereas that formed on the SS did not peel off and left material behind after alkali treatment (see Figure 5(c)). The difference between $\Delta P$ and $m_{\mathrm{f}}$ values for SS and PFA-3 is consistent with the latter deposit containing little mineral and therefore being less dense. A PFA-3 deposit with given $m_{\mathrm{f}}$ will be thicker and $\Delta P$, which is sensitive to narrowing of the duct, will therefore be larger.

CLSM was used to study whether the surface affected the local composition of the deposit. Figure 9 shows an orthogonal CLSM section of the 120 min deposit on SS. The signals indicating the presence of (a) amines, (b) calcium ions and (c) both, are shown separately. Blue indicates the amine groups present in proteins and red the presence of $\mathrm{Ca}^{2+}$ ions. The deposit appears generally uniform in composition, with some patches of variation parallel (lateral) to the surface. In the asterisked regions there are relatively more amine groups than calcium ions, suggesting a higher protein content. This variation is unlikely to arise from the surface, as the surface chemistry would be expected to affect composition uniformly near the interface at the length-scales studied. At some points the fouling layer blistered (see label 'B').

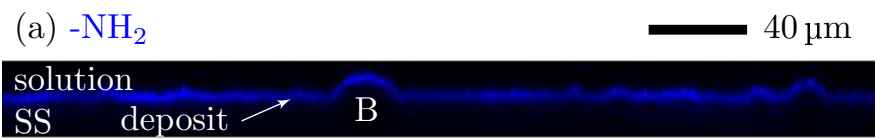

(b) $\mathrm{Ca}^{2+}$

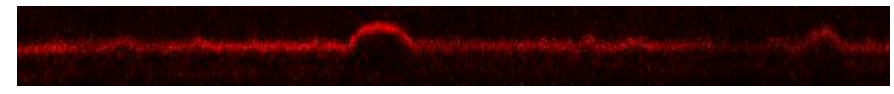

(c) $-\mathrm{NH}_{2}, \mathrm{Ca}^{2+}$

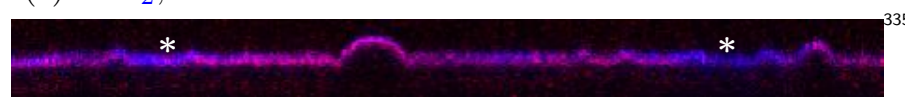

Figure 9: CLSM sections through a raw milk fouling layer on SS (see Figure $8 \mathrm{~b}$ ) taken in situ with a $10 \times$ lens. The amine and calcium ${ }^{340}$ data are shown individually in (a,b) and superimposed in (c). ' $B$ ' marks a blister and asterisks highlight lateral variations in composition.

Given the instantaneous changes in the fouling layers on apolar surfaces when subject to drying (peeling off), ${ }^{345}$ these were studied with CLSM in situ, i.e. without disassembling the fouling cell. Figure 10(a) shows an example of a deposit cross section on PFA-3. The deposit layer was considerably thicker than on SS and the apolar surface promoted the growth of a protein-dense layer extending up to ${ }^{350}$ $20 \mu \mathrm{m}$. The structure of the layer closely resembles those encountered around trapped air bubbles: an example of such a bubble on SS is shown in Figure 10(b). In contrast to the previous images, this scan was taken parallel to the evident: the protein acts as a surfactant (Gunning et al., 2004).
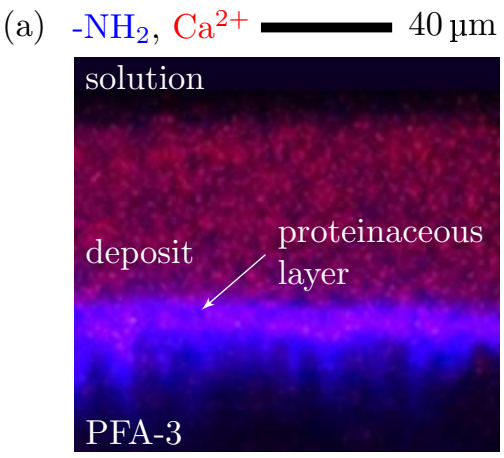

(b)
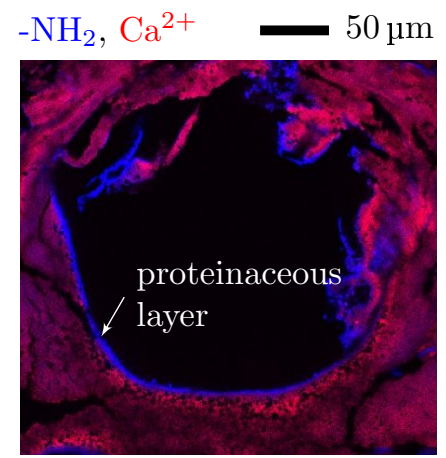

Figure 10: CLSM images showing the composition of raw milk deposit generated with the microfluidic HEX on apolar surfaces: (a) orthogonal CLSM section of a fouling layer on PFA-3 (Figure 8e). The substrate is at the base and the solution above. Image taken with $10 \times$ air lens in situ. (b) CLSM image, scanned parallel to the surface, of deposit on SS (Figure 8b) showing the cross section of an air bubble. Image taken with $40 \times$ oil immersion lens ex situ.

Bench scale testing: scale up. Figure 11 shows the evolution of fouling resistance while processing whey protein solution for five different surfaces. The surfaces tested included SS (the benchmark) and FEP-2, which had been tested in the microfluidic cell, as well as PFA and FEP variants (labelled PFA-4 and FEP-3) which had been developed given the insight provided by the microfluidic cell. In this regard the cell was used both to screen and to test candidate surfaces. In Figure 11(a), two groups of surfaces can be identified: (i) FEP-2, with a fouling rate of around $0.04 \mathrm{~m}^{2} \mathrm{~K} \mathrm{~kW}^{-1} \mathrm{~h}^{-1}$, and (ii) SS, FEP-3 and PFA-4, with a fouling rate of $0.02 \mathrm{~m}^{2} \mathrm{KkW}^{-1} \mathrm{~h}^{-1}$. No induction period was evident. Figure 11(b) shows that there was an induction period of approximately 75 min with PP.

Tests with raw milk gave insignificant changes in fouling resistance on all surfaces tested under these conditions (data not shown). The heat duty was adjusted to give the same mean surface temperature for the higher viscosity fluid, but the increased shear stress may have resulted in the low deposition rates. More importantly, O'Kennedy and Mounsey (2006) showed that caseins present in milk (but absent in WP solution) can prevent WPs from denaturing and aggregating by stabilising their structure and 


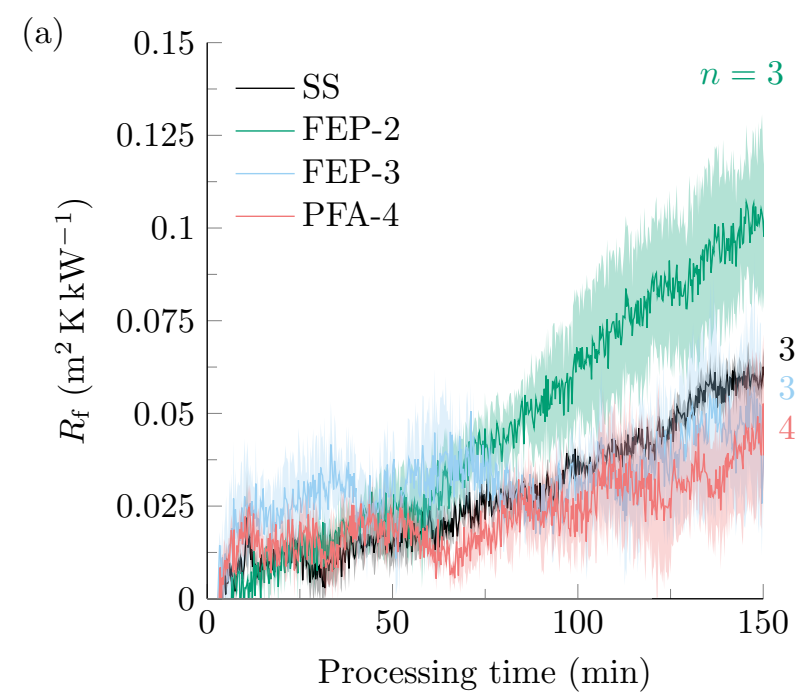

(b)

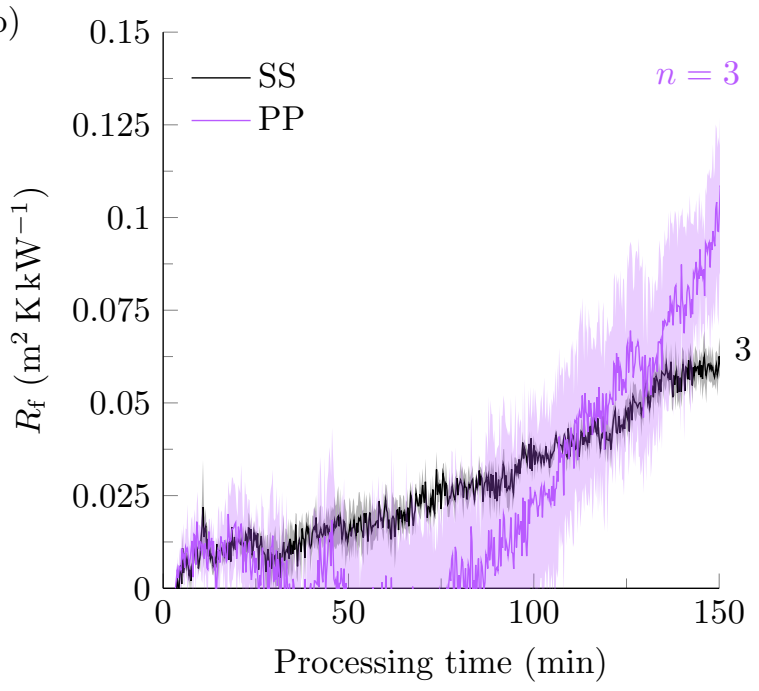

Figure 11: Fouling resistance profiles for fouling tests with benchscale HEX using WP solution. $n$ indicates the number of experiments performed. Shaded bands indicate \pm standard error.

acting as blocking agents in protein polymerisation. Proteins that assist folding and unfolding of other proteins to achieve and retain a functional structure are known as 'chaperone' proteins in the context of molecular biology (Wijayanti et al., 2014).

The associated deposit mass coverage data are presented in Figure 12. $90 \%$ confidence intervals, from repeated experiments, indicate a smaller variance than with fouling resistance. All the coatings exhibited significant forming best. Deposit coverage was reduced by $50 \%$ when replacing SS with FEP-3. Comparison of the mass coverage with the fouling resistance data allows information about the structure and composition of the fouling deposits to be extracted. Assuming the deposit to be a uniform slab, the fouling resistance is related to the layer thickness, $\delta_{\mathrm{f}}$, and thermal conductivity, $k_{\mathrm{f}}$, by $R_{\mathrm{f}}=\delta_{\mathrm{f}} / k_{\mathrm{f}}$ (Davies et al., 1997). Writing $\delta_{\mathrm{f}}=m_{\mathrm{f}} / \rho_{\mathrm{f}}$, where $\rho_{\mathrm{f}}$ is

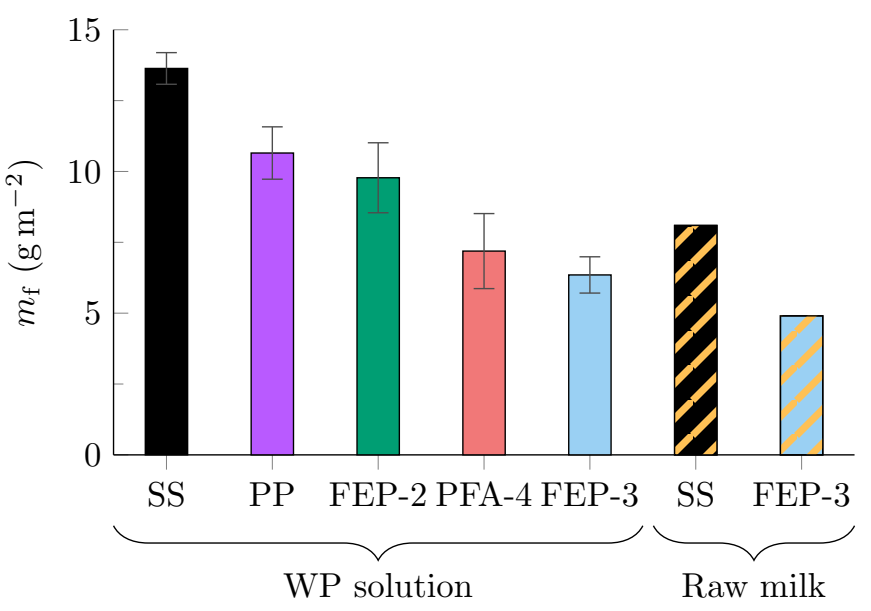

Figure 12: Deposit coverage (dry mass per area) for different surfaces tested in the bench-scale HEX for a duration of 150 min. Error bars show $90 \%$ confidence intervals.

the foulant density, gives $\rho_{\mathrm{f}} k_{\mathrm{f}}=m_{\mathrm{f}} / R_{\mathrm{f}}$. A large value of $\rho_{\mathrm{f}} k_{\mathrm{f}}$ generally indicates a dense deposit with high thermal conductivity. It should be noted that all variables $\left(\rho_{\mathrm{f}}, k_{\mathrm{f}}\right.$, $m_{\mathrm{f}}, R_{\mathrm{f}}$ ) correspond to properties of the wet layer. Here, $m_{\mathrm{f}}$ was measured after drying, so the above relationship is used to identify differences in structure and composiion rather than absolute values of $\rho_{\mathrm{f}} k_{\mathrm{f}}$. Figure 13 shows that deposit from WP solution on apolar surfaces is generally different in structure and/or composition than deposit generated on SS. This applies both for smooth PP and rough PFA-4. The deposits on apolar surfaces feature a common $\rho_{\mathrm{f}} k_{\mathrm{f}}$ value of $105 \mathrm{~kg}^{2} \mathrm{~m}^{-2} \mathrm{~s}^{-3} \mathrm{~K}^{-1}$ which is half of

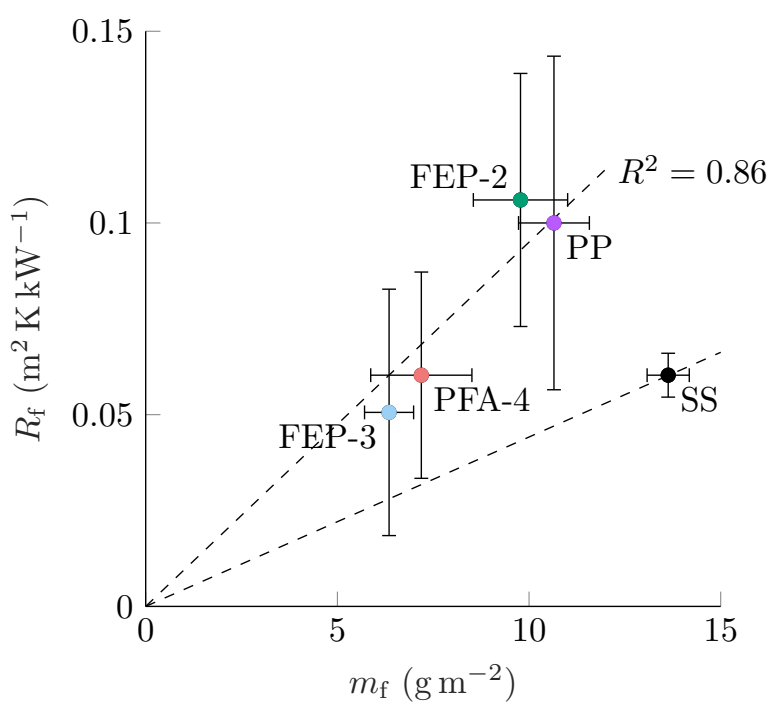

Figure 13: Relationship between final fouling resistance and whey protein dry deposit mass coverage for different surfaces tested with the bench-scale HEX. Dashed lines show root mean square fitted equation $R_{\mathrm{f}}=m_{\mathrm{f}} / \rho_{\mathrm{f}} k_{\mathrm{f}}$ to find values of $\rho_{\mathrm{f}} k_{\mathrm{f}}$ for polymer surfaces and SS. For polymer surfaces $\rho_{\mathrm{f}} k_{\mathrm{f}}=105 \mathrm{~kg}^{2} \mathrm{~m}^{-2} \mathrm{~s}^{-3} \mathrm{~K}^{-1}$ and for $\mathrm{SS} \rho_{\mathrm{f}} k_{\mathrm{f}}=226 \mathrm{~kg}^{2} \mathrm{~m}^{-2} \mathrm{~s}^{-3} \mathrm{~K}^{-1}$. Error bars show $90 \%$ confidence intervals. 
that estimated for deposits on SS $\left(226 \mathrm{~kg}^{2} \mathrm{~m}^{-2} \mathrm{~s}^{-3} \mathrm{~K}^{-1}\right)$. This indicates that the latter deposit is significantly denser and/or more thermally conductive. A similar $\rho_{\mathrm{f}} k_{\mathrm{f}}$ value for $\mathrm{SS}\left(221 \mathrm{~kg}^{2} \mathrm{~m}^{-2} \mathrm{~s}^{-3} \mathrm{~K}^{-1}\right)$ was reported by Tuladhar et al. (2002) for WP fouling deposit, although they employed ${ }_{435}$ only wet layer properties in their analysis.

The calcium contents of selected deposits were determined with inductively coupled plasma mass spectroscopy (ICP-MS) and the results are reported in Table 2. The calcium fraction of the deposits from WP solution was low 440 for all surfaces and matched approximately the fraction of $6 \mathrm{mg} \mathrm{g}^{-1}$ in the WP powder. This indicates that the WP deposits had similar composition but differed in structure.

The calcium content of deposits from the raw milk was noticeably higher, by a factor of approximately 10 . Taking ${ }_{445}$ there to be $0.1 \mathrm{~g} \mathrm{~g}^{-1}$ solids in raw milk, the calcium content in the raw milk fouling deposits was about 10 times higher than in milk solids. The SS deposit contained $25 \%$ more calcium than FEP-3 deposit. The calcium fractions determined in this work lie within the range reported in the literature. Other researchers have measured a calcium fraction of around $5 \% \mathrm{~g} \mathrm{~g}^{-1}$ in deposits from raw milk generated at $100{ }^{\circ} \mathrm{C}$ on SS after $120 \mathrm{~min}$ of processing (Foster et al., 1989). Visser and Jeurnink (1997) determined $15.7 \% \mathrm{~g} \mathrm{~g}^{-1}$ calcium in deposit generated from skim milk at $69-85^{\circ} \mathrm{C}$ bulk temperature.

\section{Discussion}

Adhesion of a mineral-rich sub-layer on SS, likely to be mainly calcium phosphate, was strong after $120 \mathrm{~min}$ of processing with the micro-scale test cell at a surface temperature of $85^{\circ} \mathrm{C}$ (see Figure 8c). Foster et al. (1989), working with SS at similar temperatures and for the same processing period, also reported a high calcium phosphate content at the deposit-substrate interface.

Apolar surfaces and air bubbles favoured protein deposition. Adsorption experiments by Luey et al. (1991) support these findings: they reported more $\beta$-LG adsorption on hydrophobic silicon than on hydrophilic silicon, although their study was performed at $15.6^{\circ} \mathrm{C}$. Because s low density, air can be considered as an apolar, low surface energy material in this context, in effect adsorbing similar proteinaceous matter as seen in Figure 10(b). Intermolecular forces of a material decay on the nanometrescale (van Oss, 2003). Comparing this with the proteina-
Figure 10 suggests that the affinity for low polarity species is propagated as the fouling layer grows.

The surface energies of the tested surface materials and denatured $\beta$-LG were determined by contact angle measurements. The materials were found to have $\gamma^{+} \approx 0$, i.e. they are monopolar. The remaining contributions to surface energy from $\gamma^{\mathrm{LW}}$ and $\gamma^{-}$are plotted as dots in Figure 14(a). According to Equation 2 the affinity of apolar surfaces to promote proteinaceous deposit can be explained by estimating the interfacial free energy of interaction, $\Delta G_{123}^{\mathrm{IF}}$, when denatured $\beta$-LG (subscript 1 ) adsorbs to a surface (2) in an aqueous environment (3). Contours of constant $\Delta G_{123}^{\mathrm{IF}}$ plotted in Figure 14(a) indicate strong interaction of $\beta$-LG with other hydrophobic materials in water (c.f. $-65 \mathrm{~mJ} \mathrm{~m}^{-2}$ for FPs and $-23 \mathrm{~mJ} \mathrm{~m}^{-2}$ for
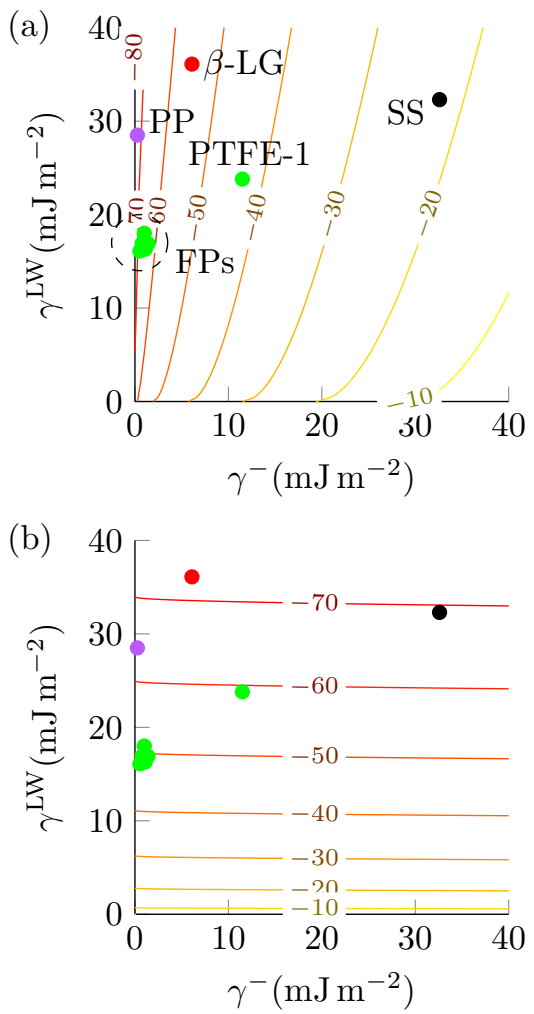

Figure 14: Contours of interfacial free energy of interaction, $\Delta G_{123}^{\mathrm{IF}}$ $\left(\mathrm{mJ} \mathrm{m}^{-2}\right)$, of (subscript 1) denatured BLG and (2) monopolar surfaces, in (3) (a) water and (b) air. Monopolar surface electron donor, $\gamma^{-}$, and apolar, $\gamma^{\mathrm{LW}}$, contributions to surface energy are displayed on the axes. The surface energy of denatured $\beta$-LG was determined by contact angle measurements on a hot air-dried film, see Table 1.

Table 2: Calcium fraction of foulant solution dry solids and fouling deposits used in the bench-scale HEX determined by ICP-MS. The raw milk dry solids calcium fraction is calculated by assuming $0.1 \mathrm{~g} \mathrm{~g}^{-1}$ dry solids.

\begin{tabular}{|c|c|c|c|c|c|c|c|}
\hline Foulant & \multicolumn{5}{|c|}{ WP solution } & \multicolumn{2}{|c|}{ raw milk } \\
\hline Solution solids calcium fraction $\left(\mathrm{mg} \mathrm{g}^{-1}\right)$ & & & 6 & & & & 10 \\
\hline Surface & $\mathrm{SS}$ & $\mathrm{PP}$ & FEP-2 & PFA-4 & FEP-3 & SS & FEP-3 \\
\hline Deposit calcium fraction $\left(\mathrm{mg} \mathrm{g}^{-1}\right)$ & 5.1 & 6.8 & 7.5 & 7.3 & 6.6 & 92.3 & 74.1 \\
\hline
\end{tabular}


metals). The inter-particle interaction of denatured $\beta$-LG describes the tendency of $\beta$-LG to form aggregates and is therefore an estimate of the cohesive strength of the foul- 485 ing material. The free energy of inter-particle interaction ${ }_{450}$ is calculated to be $\Delta G_{113}^{\mathrm{IF}}=-2 \gamma_{13}=-56 \mathrm{~mJ} \mathrm{~m}^{-2}$ (with subscripts 1: $\beta$-LG, 3: water, see also Figure 1 (b) for visualisation), even though this is not accounting for chemical reactions within the fouling deposit.

Dried deposits warped and detached from apolar surfaces, indicating stronger cohesion within the layer than adhesion to the surface. This view is supported by considering that removing water from the deposit (i.e. medium 3 becomes air) results in stronger interactions within the ${ }_{495}$ fouling deposit: $\Delta G_{113}^{\mathrm{IF}}=-2 \gamma_{1}=-72 \mathrm{~mJ} \mathrm{~m}^{-2}$ (with subscripts 1: $\beta$-LG, 3: air). Figure 14(b) demonstrates that the adhesion to apolar surfaces remains largely unaffected by drying while the adhesion to PTFE-1 and SS increases markedly. On apolar surfaces the deposit cohesion be-500 comes stronger than adhesion. On SS, drying decreases $\Delta G_{123}^{\mathrm{IF}}$ of $\beta$-LG and the surface three-fold to $-77 \mathrm{~mJ} \mathrm{~m}^{-2}$, giving a reason for the strong adhesion of dry deposit to SS.

Simple crystal nucleation theories such as that by Rieke ${ }_{505}$ (1997) suggest minerals should also form on FPs. The interfacial free energies of three common forms of calcium phosphate, which are closely related to the interfacial free energies of heterogeneous nucleation, are depicted in Figure 15. The plots suggest that apolar surfaces are attrac- -510 tive for DCPD, OCP, and HAP to nucleate and to adhere. Nucleation and adhesion to SS is calculated to be much less attractive. This was not seen in the experimental observations and there might be several reasons for this:

(i) Although calcium phosphate nucleation and/or calcium phosphate particle adhesion is promoted by apolar surfaces, fast adsorption of protein could be kinetically favoured. This view is supported by Visser and Jeurnink (1997) who argued that the first layer to be adsorbed is proteinaceous but can change composition over time (Foster et al., 1989; Foster and Green, 1990). Proteins adsorbed to hydrophobic materials expose their hydrophobic side chains (Miriani et al., 2014), creating a hydrophobic interfacial region. For subsequent nucleation of calcium phosphate between adsorbed protein and FP, well hydrated calcium and phosphate ions have to leave parts of their solvation shell to diffuse through regions of hydrophobic matter - this is likely to make the process unfavourable.

(ii) Wu et al. (1997) pointed out that arguments based on free energy of heterogeneous nucleation fail to explain why calcium phosphate does not nucleate on apolar polymers in biomineralisation. They concluded that electron donor and acceptor sites are a necessary condition for heterogeneous nucleation by providing a template for ordered lattice ion deposition. The current model does not consider local charge interactions of individial ions.

(iii) Another reason for the absence of a mineral baselayer on FPs might be the geometric lattice mismatch between calcium phosphate and unordered polymer strands. Amjad (1998) noted that kinetics and energetics of calcium phosphate overgrowth depend strongly on the spacing and structure of the lattices involved as well as their relative orientations.

(iv) The majority of calcium phosphate is bound in casein micelles, i.e. the interactions of casein micelles are be more important than assumed.

Expanding on hypothesis (i) one can calculate the free energy of interaction of a calcium phosphate (CP) layer developing between previously adsorbed $\beta$-LG and the surface:

$$
\begin{aligned}
\Delta G^{\mathrm{CP} \text { integration }}= & \Delta G_{\mathrm{BLG}, \mathrm{CP}, \text { water }}^{\mathrm{IF}}+\Delta G_{\mathrm{CP}, \text { surface, water }}^{\mathrm{IF}} \\
& -\Delta G_{\mathrm{BLG}, \text { surface, water }}^{\mathrm{IF}} \cdot
\end{aligned}
$$

(a) $\Delta G_{123}^{\mathrm{IF}}$ with 1: DCPD

2: surface 3: water

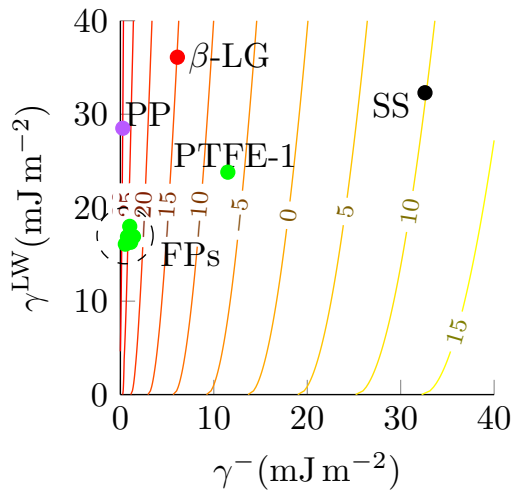

(b) $\Delta G_{123}^{\mathrm{IF}}$ with 1: OCP

2: surface 3 : water

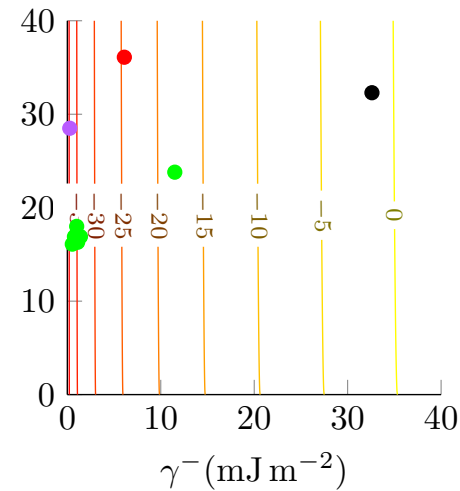

(c) $\Delta G_{123}^{\mathrm{IF}}$ with $1: \mathrm{HAP}$

2: surface 3: water

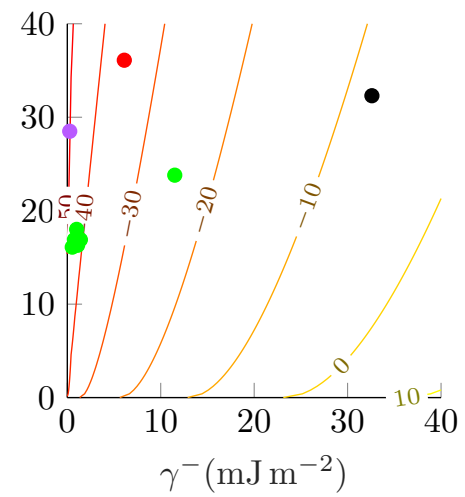

Figure 15: Contours of interfacial free energy of interaction, $\Delta G_{123}^{\mathrm{IF}}\left(\mathrm{mJ} \mathrm{m}^{-2}\right)$, (subscript 1) of (a) DCPD (b) OCP (c) HAP and (2) monopolar surfaces in (3) water. Monopolar surface electron donor, $\gamma^{-}$, and apolar, $\gamma^{\mathrm{LW}}$, contributions to surface energy are displayed on the axes. The surface energies of DCPD, OCP and HAP were taken from Wu and Nancollas (1998). 
This free energy is calculated for DCPD, OCP and HAP in Figure 16. DCPD is unlikely to form since $\Delta G^{\mathrm{DCPD}}$ integration is positive for all surfaces in Figure 16(a). The generation ${ }^{50}$ of an OCP layer is marginally attractive on SS in Figure 16(b). It is, however, eventually expected for HAP to form, as the associated free energy reduction is largest for all surfaces (see Figure 16c). The reduction in free energy is about twice as high for SS than for apolar surfaces. Within this framework the integration of a mineral layer between $\beta$-LG and the SS surface could thus be explained ${ }^{555}$ - bearing in mind the simplifications and limitations of the approach.

\section{Conclusions}

The micro-scale fouling cell has been used to identify candidate surfaces to study fouling from bacterially active raw milk. Experiments at the two different length scales both demonstrated that fluoropolymers can mitfouling from raw milk and whey protein solution. This reduction was generally more significant in terms of ${ }_{570}$ dry mass coverage than pressure drop and fouling resistance evolution. The raw milk fouling deposits formed in the micro-scale HEX experiments featured more protein at the substrate-fouling interface on the apolar surfaces. ${ }_{575}$

In the bench-scale HEX these surfaces also gave deposits with lower calcium calcium content. The deposits formed on apolar surfaces had a lower density and/or thermal conductivity, indicating that the microstructure of the ${ }_{580}$ deposit was affected by the surface. Apolar surfaces gave spongier WP deposits, although the deposit's protein and mineral composition was unaffected by the nature of the surface.

The attraction of denatured protein towards apolar surfaces and the formation of a calcium phosphate layer on SS at later stages of raw milk fouling was explained with arguments based on the interfacial free energy of in-590 teraction of these materials in water.

\section{Acknowledgements}

A PhD studentship for OMM from Chemours and the provision of raw milk by the University of Cambridge Park Farm are gratefully acknowledged.

\section{References}

Amjad, Z., 1998. Calcium Phosphates in Biological and Industrial Systems. Springer Science and Business Media, NY, US.

Bansal, B., Chen, X.D., 2006. A critical review of milk fouling in heat exchangers. Compr. Rev. Food Sci. Food Saf. 5, 27-33. doi:10. 1111/j.1541-4337.2006.tb00080.x.

Barish, J.A., Goddard, J.M., 2013. Anti-fouling surface modified stainless steel for food processing. Food Bioprod. Process. 91, 352-361. doi:10.1016/j.fbp.2013.01.003.

Barish, J.A., Goddard, J.M., 2014. Stability of nonfouling stainless steel heat exchanger plates against commercial cleaning agents. J. Food Eng. 124, 143-151. doi:10.1016/j.jfoodeng.2013.10.009.

Bergman, T.L., Incropera, F.P., 2011. Fundamentals of Heat and Mass Transfer. Wiley, NYC, US.

Blanpain-Avet, P., André, C., Khaldi, M., Bouvier, L., Petit, J., Six, T., Jeantet, R., Croguennec, T., Delaplace, G., 2016. Predicting the distribution of whey protein fouling in a plate heat exchanger using the kinetic parameters of the thermal denaturation reaction of $\beta$-lactoglobulin and the bulk temperature profiles. Journal of dairy science 99, 9611-9630. doi:10.3168/jds.2016-10957.

Boxler, C., Augustin, W., Scholl, S., 2013. Influence of surface modification on the composition of a calcium phosphate-rich whey protein deposit in a plate heat exchanger. Dairy Sci. Technol. 94, 17-31. doi:10.1007/s13594-013-0142-5.

Davies, T., Henstridge, S., Gillham, C., Wilson, D., 1997. Investigation of whey protein deposit properties using heat flux sensors. Food Bioprod. Process. 75, 106-110. doi:10.1205/ 096030897531414.

Dupré, M.A., 1869. Théorie Méchanique de la Chaleur. GauthierVillars, Paris, FR.

Fernández-Martín, F., 1972. Influence of temperature and composition on some physical properties of milk and milk concentrates. II. Viscosity. J. Dairy Res. 39, 75-82. doi:10.1017/ S0022029900013868.

Foster, C.L., Britten, M., Green, M.L., 1989. A model heat-exchange apparatus for the investigation of fouling of stainless steel surfaces by milk I. Deposit formation at $100^{\circ}$ C. J. Dairy Res. 56, 201-209. doi:10.1017/S002202990002642X.
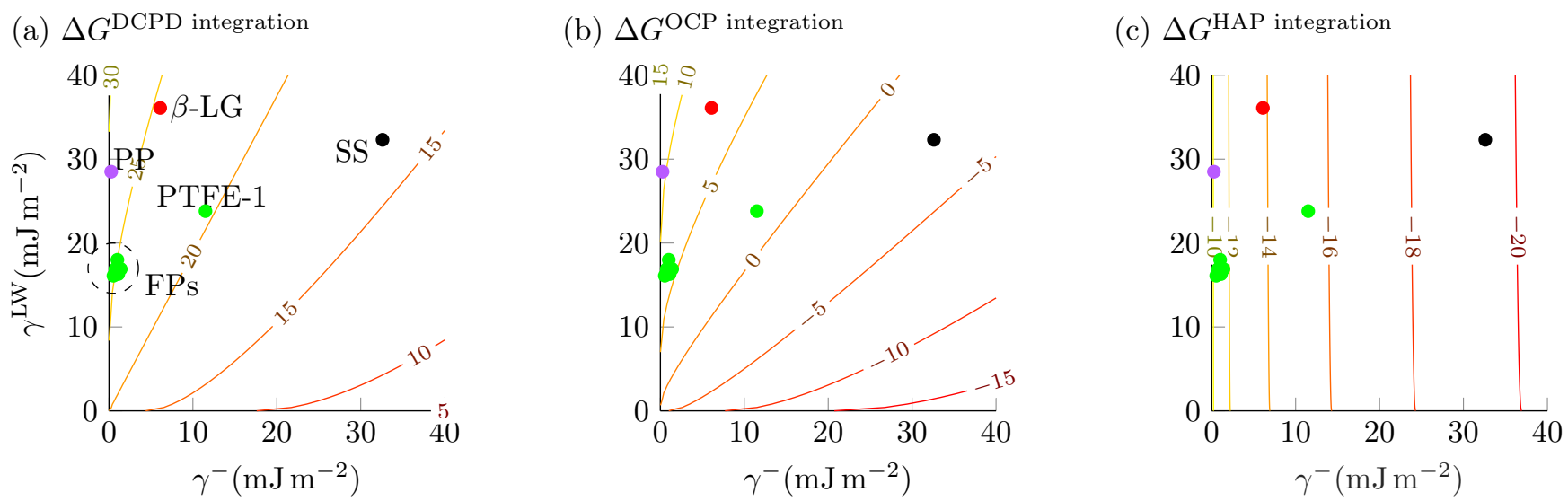

Figure 16: Contours of the change in interfacial free energy, $\Delta G^{\mathrm{CP}}$ integration $\left(\mathrm{mJ} \mathrm{m}^{-2}\right.$ ), of a layer of (a) DCPD (b) OCP and (c) HAP forming between adsorbed BLG and the surface. Monopolar surface electron donor, $\gamma^{-}$, and apolar, $\gamma^{\mathrm{LW}}$, contributions to surface energy are displayed on the axes. The surface energies of DCPD, OCP and HAP were taken from Wu and Nancollas (1998). 
Foster, C.L., Green, M.L., 1990. A model heat exchange apparatus for the investigation of fouling of stainless steel surfaces by milk II. Deposition of fouling material at $140{ }^{\circ} \mathrm{C}$, its adhesion and depth profiling. J. Dairy Res. 57, 339-348. doi:10.1017/665 S0022029900026996.

Fowkes, F.M., 1963. Additivity of intermolecular forces at interfaces. I. Determination of the contribution to surface and interfacial tensions of dispersion forces in various liquids. J. Phys. Chem. 67, 2538-2541. doi:10.1021/j100806a008.

600 Gomes da Cruz, L., Ishiyama, E.M., Boxler, C., Augustin, W. Scholl, S., Wilson, D.I., 2015. Value pricing of surface coatings for mitigating heat exchanger fouling. Food Bioprod. Process. 93, 343-363. doi:10.1016/j.fbp.2014.05.003.

Gunning, P.A., Mackie, A.R., Gunning, A.P., Wilde, P.J., Wood-675 ward, N.C., Morris, V.J., 2004. The effect of surfactant type on protein displacement from the airwater interface. Food Hydrocoll. 18, 509-515. doi:10.1016/j.foodhyd.2003.08.008.

Hagsten, C., Altskär, A., Gustafsson, S., Lorén, N., Ham, L., Innings, F., Paulsson, M., Nylander, T., 2016. Composition and structure680 of high temperature dairy fouling. Food Struct. 7, 13-20. doi:10. 1016/j.foostr.2015.12.002.

Huang, K., Goddard, J.M., 2015. Influence of fluid milk product composition on fouling and cleaning of NiPTFE modified stainless steel heat exchanger surfaces. J. Food Eng. 158, 22-29. doi:10.685 1016/j.jfoodeng.2015.02.026.

Israelachvili, J.N., 2011. Intermolecular and Surface Forces. volume 3. Elsevier, Waltham, MA, US.

Lefevre, C., Kang, H.C., Haugland, R.P.R.P., Malekzadeh, N., Arttamangkul, S., Haugland, R.P.R.P., 1996. Texas Red-X and rhodamine Red-X, new derivatives of sulforhodamine 101 and lissamine rhodamine B with improved labeling and fluorescence properties. Bioconjug. Chem. 7, 482-489. doi:10.1021/bc960034p.

Luey, J.K., McGuire, J., Sproull, R.D., 1991. The effect of $\mathrm{pH}$ and $\mathrm{NaCl}$ concentration on adsorption of $\beta$-lactoglobulin at hydrophilic and hydrophobic silicon surfaces. J. Colloid Interface Sci. 143, 489-500. doi:10.1016/0021-9797(91) 90282-D.

Magens, O.M., Hofmans, J.F.A., Wilson, D.I., 2017. A fouling micro-system for investigating fluoropolymer antifouling coatings in bovine milk pasteurisation, in: Heat Exch. Fouling Clean. Conf., Aranjuez, Spain. pp. 140-147. URL: http://www . heatexchanger-fouling.com/papers/papers2017/19_Magens_A\% 20 Fouling $\% 20$ Micro-system $\% 20$ for $\% 20$ Investigating.pdf.

Mérian, T., Goddard, J.M., 2012. Advances in nonfouling materials: Perspectives for the food industry. J. Agric. Food Chem. 60, 29432957. doi:10.1021/jf204741p.

Miriani, M., Eberini, I., Iametti, S., Ferranti, P., Sensi, C., Bonomi, F., 2014. Unfolding of beta-lactoglobulin on the surface of polystyrene nanoparticles: Experimental and computational approaches. Proteins Struct. Funct. Bioinforma. 82, 1272-1282. doi:10.1002/prot. 24493 .

O'Kennedy, B.T., Mounsey, J.S., 2006. Control of Heat-Induced Aggregation of Whey Proteins Using Casein. J. Agric. Food Chem. 54, 5637-5642. doi:10.1021/jf0607866.

van Oss, C.J., Chaudhury, M.K., Good, R.J., 1987. Monopolar surfaces. Adv. Colloid Interface Sci. 28, 35-64. doi:10.1016/ 0001-8686(87) 80008-8.

van Oss, C.J., Good, R.J., 1992. Prediction of the solubility of polar polymers by means of interfacial tension combining rules. Langmuir 8, 2877-2879. doi:10.1021/la00048a006.

650 Piepiórka-Stepuk, J., Tandecka, K., Jakubowski, M., 2016. An analysis of milk fouling formed during heat treatment on a stainless steel surface with different degrees of roughness. Czech J. Food Sci. 34, 271-279. doi:10.17221/466/2015-CJFS.

Rieke, P.C., 1997. Application of Van Oss-Chaudhury-Good theory of wettability to interpretation of interfacial free energies of heterogeneous nucleation. J. Cryst. Growth 182, 472-484. doi:10.1016/S0022-0248(97)00357-6.

Rosmaninho, R., Melo, L.F., 2007. Effect of proteins on calcium phosphate deposition in turbulent flow as a function of surface properties. Exp. Therm. Fluid Sci. 32, 375-386. doi:10.1016/j . expthermflusci.2007.04.012
Thomas, D., Tovey, S.C., Collins, T.J., Bootman, M.D., Berridge, M.J., Lipp, P., 2000. A comparison of fluorescent $\mathrm{Ca}^{2+}$ indicator properties and their use in measuring elementary and global $\mathrm{Ca}^{2+}$ signals. Cell Calcium 28, 213-223. doi:10.1054/ceca.2000.0152.

Tuladhar, T.R., Paterson, W.R., Wilson, D.I., 2002. Thermal conductivity of whey protein films undergoing swelling. Food Bioprod. Process. 80, 332-339. doi:10.1205/096030802321154862.

van Oss, C.J., 2003. Long-range and short-range mechanisms of hydrophobic attraction and hydrophilic repulsion in specific and aspecific interactions. J. Mol. Recognit. 16, 177-190. doi:10.1002/ jmr. 618 .

Visser, J., Jeurnink, T.J.M., 1997. Fouling of heat exchangers in the dairy industry. Exp. Therm. Fluid Sci. 14, 407-424. doi:http: //dx.doi.org/10.1016/S0894-1777(96)00142-2.

Walstra, P., Wouters, J.T.M., Geurts, T.J., 2005. Dairy Science and Technology. volume 2. Taylor \& Francis, Boca Raton, FL, US. doi:10.1021/op0101005.

Wijayanti, H.B., Bansal, N., Deeth, H.C., 2014. Stability of Whey Proteins during Thermal Processing: A Review. Compr. Rev. Food Sci. Food Saf. 13, 1235-1251. doi:10.1111/1541-4337.12105.

Wu, W., Nancollas, G.H., 1998. The dissolution and growth of sparingly soluble inorganic salts: a kinetics and surface energy approach. Pure Appl. Chem. 70, 1867-1872. doi:10.1351/ pac199870101867.

Wu, W., Zhuang, H., Nancollas, G.H., 1997. Heterogeneous nucleation of calcium phosphates on solid surfaces in aqueous solution. J. Biomed. Mater. Res. 35, 93-9. doi:10.1002/(SICI) 1097-4636 (199704) 35 : 1<93: :AID-JBM9>3 . 0. CO;2-H. 